\title{
An empirical study of entrepreneurship education and teaching in Colleges and Universities under the concept of sustainable development
}

\author{
He JIANG ${ }^{1, \mathrm{a}}$, Yonghui $\mathrm{CAO}^{* 1, \mathrm{~b}}$ \\ ${ }^{1}$ Department of Business Administration Guangzhou College of Technology and Business Guangzhou, China
}

\begin{abstract}
This paper applies the quality function deployment (QFD) theory to improve the teaching quality of entrepreneurship education, and puts forward the QFD model of entrepreneurship education teaching quality improvement. First of all, the paper constructs a series of quality houses by mining the customers' demand for entrepreneurship education, including the quality house of teaching quality design, the quality house of teaching quality implementation and the quality house of teaching quality control. The entrepreneurship education customer demands are expanded to the specific steps of teaching process, and the establishment of entrepreneurship education teaching target and a series of implementation process, to improve the teaching quality of entrepreneurship education in local universities through the realization of these goals.
\end{abstract}

\section{Introduction}

In order to improve the innovation and entrepreneurship ability of college students and form a good innovation and entrepreneurship education atmosphere, we need to build a perfect innovation and entrepreneurship cultivation system[1-2]. The Ministry of education has issued the notice of "basic requirements for entrepreneurship education in ordinary undergraduate schools". The document points out: to carry out entrepreneurship education in ordinary colleges and universities is a strategic measure to serve the country, accelerate the transformation of economic development mode, and build an innovative country and a powerful human resource country. It is an important way to deepen the teaching reform of higher education, improve the quality of personnel training, and promote the all-round development of college students [13]. It is also an important measure to implement entrepreneurship to promote employment and promote the full employment of college graduates. With the "entrepreneurship foundation" course included in the undergraduate compulsory, innovation and entrepreneurship education has once again become the focus of education research. Subsequently, the CDEP platform of the United Nations Youth Employment Network China demonstration project opened an innovation and entrepreneurship system. This also indicates that the vigorous development of innovation and entrepreneurship education in China is in line with the world. Some scholars have studied entrepreneurship education with various methods, and achieved positive results [4-6].
However, there are few papers using QFD theory to study entrepreneurship education. QFD is a popular market-oriented product design and development process in the world. It is a quality management method to control the quality of products [7]. It can provide guidance for the curriculum of public entrepreneurship education in Colleges and universities. According to the theory of quality function deployment, some scholars put forward that the curriculum of public entrepreneurship education in Colleges and universities should meet the needs of students' all-round development according to the needs of society, and integrate the public entrepreneurship education into the talent training system and run through the whole process of talent training in combination with the characteristics of colleges and universities. That is to say, the public entrepreneurship education curriculum is integrated into the "universal education curriculum system, professional education curriculum system" of the school.

Liu Lipeng (2020) based on QFD theory explored the path of Vocational College Students' innovation and entrepreneurship ability training. He believes that under the background of the national innovation driven development strategy, it is necessary for vocational colleges to cultivate students' innovation and entrepreneurship ability, and QFD theory plays a guiding role in the cultivation of students' innovation and entrepreneurship ability. Starting from the connotation of QFD theory, this paper scientifically expounds the guidance of QFD theory on the cultivation of students' innovation and entrepreneurship ability, analyzes the main problems in the cultivation of students' innovation and entrepreneurship ability in Vocational Colleges by combining theory with practice, and puts forward the relevant paths to solve the problems, so as to realize the purpose of promoting the cultivation of students' 
innovation and entrepreneurship ability[8]. Teng Fei (2019) studied the teaching design of innovation and entrepreneurship education in Universities for Nationalities from the perspective of quality. He introduced QFD into university teaching design. Through the practice of innovation and entrepreneurship education in ethnic universities, he proved that QFD method is effective and helpful to innovation and entrepreneurship education in ethnic universities. From the perspective of total quality management, the effective connection between teaching needs and teaching design can be achieved, which provides a reference for the innovation and entrepreneurship education in ethnic universities[9]. Zhang Junjie and Yang $\mathrm{Li}$ (2019) conducted an empirical study on the entrepreneurial ability of Application-oriented College Students Based on QFD theory through interview and questionnaire survey, and designed the demand expansion table of College Students' entrepreneurial ability. Through the establishment of QFD relationship matrix, the importance and satisfaction of entrepreneurial needs are calculated and analyzed, and then the key influencing factors and improvement factors of College Students' entrepreneurial ability are obtained. On this basis, this paper puts forward the countermeasures to improve the entrepreneurial ability from six aspects, including the entrepreneurial curriculum system, entrepreneurial teachers, entrepreneurial ability building, entrepreneurial ability evaluation, entrepreneurial service platform and entrepreneurial security system[10]. Li Ning believes that QFD theory plays an increasingly important role in the cultivation of entrepreneurial talents in Colleges and universities, and also puts forward higher requirements for the cultivation of entrepreneurial talents in Colleges and universities[11]. Under the guidance of QFD theory, colleges and universities should firmly establish the entrepreneurial talent training concept with improving quality as the core, adhere to the entrepreneurial talent training mode with market and students' needs as the basis, build the entrepreneurial talent training platform with diversification and efficiency as the focus, and build the entrepreneurial talent training system with full participation and all-round goal.

Next, this paper will analyze the teaching process of entrepreneurship education based on QFD theory, so as to provide theoretical support for improving the quality of entrepreneurship education in Colleges and universities in China.

\section{EVALUATED MEASUREMENTS}

\subsection{Identification and analysis the demand of entrepreneurship education}

In order to analyze customer demand, we should make clear the customer targets of entrepreneurship education in local universities first. The goal of local universities entrepreneurship education is to cultivate students' entrepreneurial spirit, entrepreneurial awareness and entrepreneurial skills and better adapt to the passion and ability of future work, promote the whole society to lay the foundation for the prosperity of entrepreneurial activities.
Therefore, entrepreneurship education customers are students, but the students have not formed a system of business knowledge and no business experience. Therefore, the customer demand of entrepreneurship education is from the students, teachers and people who have entrepreneurial experience.

This study investigated and interviewed 100 undergraduates, 30 teachers and 40 entrepreneurs or selfemployed entrepreneurs in a local university. A total of 170 questionnaires were issued and 152 valid questionnaires were collected, with an effective recovery rate of $89.4 \%$. After merging and classifying the information, we use the KJ method (affinity chart) to sort out the customer demand, and decompose the demands into three levels. The three horizontal demands items are shown in table 1. The evaluation of the importance is carried out according to the digital scale from 1 to 5 , and is revised from the angle of the teacher's demand. Finally, the importance of each quality demand is evaluated.

\subsection{Teaching quality planning}

The teaching quality plan for entrepreneurship education is shown in table 1. First of all, a domestic university and a foreign university as competitors, conduct market competitive assessments of customer demands, in order to judge the two in meeting customer reqirement for competitive ability. With digital $1 \sim 5$ indicating customer satisfaction with a course demand, 5 indicated great satisfaction, and 1 indicated very dissatisfied.

According to the importance degree of customer demands and the analysis result of competitive assessment, the target quality and differentiation degree of domestic universities can be set up. As for the demand with high importance degree, and the high level of the local universities and the low level of the foreign universities, which can be used as the characteristic point of the entrepreneurship education as a differentiation strategy? For the demand with high importance degree, but the local university reached a low level, while foreign universities reached a high level, at least the quality objectives will be set as foreign universities equivalent, such demands can not become characteristic points. For the demand with high importance degree, but local and foreign universities have reached a relatively low level of demand, through the quality objectives set to higher than foreign universities, so that the project may become a feature. Based on the above, we can set up the target quality.

Horizontal improvement rate $=$ target quality / local universities, which indicates the level of target quality of local universities needs to be improved. Absolute importance degree $=$ importance degree evaluation * horizontal improvement rate * improvement importance degree. $1.5,1.2,1$ is used to quantify the improvement importance degree, the absolute importance degree is calculated, and the percentage of each is the relative importance degree of demands.

It can be seen from table 1: the innovation spirit(13.23\%), entrepreneurship practice knowledge $(12.38 \%)$, innovation ability $(13.17 \%)$, professional and technical ability (12.37\%) pay more attention to such needs, 
these needs should be the focal point in the implementation of entrepreneurship education. These demands have a large proportion, and these demands should be the focus point in the implementation of entrepreneurship education in local universities.

Table 1 Teaching quality planning of entrepreneurship education

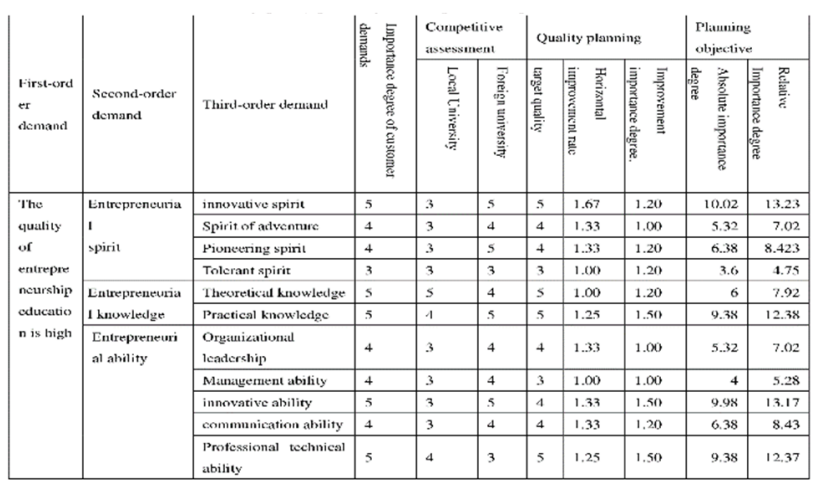

\subsection{Teaching quality designing of entrepreneurship education}

Through expert scoring, the demands and importance degree of entrepreneurship education (Table 1) are related to the teaching design process of entrepreneurship education. Accordingly, the entrepreneurship education design HOQ of Table 2 is established.

Table 2 the house of quality about teaching quality designing of entrepreneurship education

\begin{tabular}{|c|c|c|c|c|c|c|c|c|c|c|c|c|c|}
\hline \multirow{2}{*}{\multicolumn{4}{|c|}{$\begin{array}{l}\text { Foritrepreneurship } \\
\text { education demands quality measures }\end{array}$}} & \multirow{3}{*}{$\begin{array}{l}\text { Relaive } \\
\text { Importan- } \\
\text { ce degrees }\end{array}$} & \multicolumn{3}{|c|}{ Training plan } & \multicolumn{3}{|c|}{ Eaching process } & \multicolumn{3}{|c|}{\begin{tabular}{|l|}
$\begin{array}{l}\text { assessinemt } \\
\text { system }\end{array}$ \\
\end{tabular}} \\
\hline & & & & & \multirow{2}{*}{ 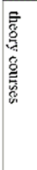 } & \multirow{2}{*}{ 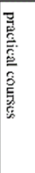 } & \multirow{2}{*}{ 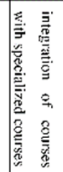 } & \multirow{2}{*}{ 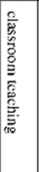 } & \multirow{2}{*}{ 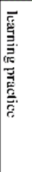 } & \multirow{2}{*}{ 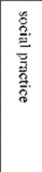 } & \multirow{2}{*}{. } & \multirow{2}{*}{ 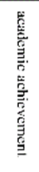 } & \multirow{2}{*}{ 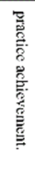 } \\
\hline $\begin{array}{l}\text { First- } \\
\text { urder } \\
\text { deman- }\end{array}$ & $\begin{array}{l}\text { Second- } \\
\text { order } \\
\text { demand }\end{array}$ & \multicolumn{2}{|c|}{ Third-order demand } & & & & & & & & & & \\
\hline \multirow{11}{*}{ 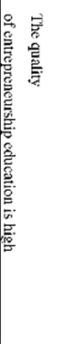 } & \multirow{4}{*}{$\begin{array}{l}\text { Enirsprencur-i } \\
\text { al spirit }\end{array}$} & \multicolumn{2}{|c|}{ innovative spirit } & 13.23 & 3 & 3 & 0 & 3 & 3 & 3 & 1 & 0 & 5 \\
\hline & & \multicolumn{2}{|c|}{ Spirit of adventure } & 7.02 & 1 & 1 & 0 & 1 & 3 & 3 & 0 & 0 & 1 \\
\hline & & \multicolumn{2}{|c|}{ Pioncering spirit } & 8.42 .3 & 3 & 3 & 0 & 1 & 3 & 3 & 0 & (1) & 3 \\
\hline & & \multicolumn{2}{|c|}{ Tolterant spirit } & 4.75 & 1 & 1 & 0 & 1 & 1 & 3 & 0 & 0 & 0 \\
\hline & \multirow{2}{*}{$\begin{array}{l}\text { Entrepreneur-i } \\
\text { al knowludgc }\end{array}$} & \multicolumn{2}{|c|}{$\begin{array}{l}\text { Theorctical } \\
\text { knowledge }\end{array}$} & 7.92 & 5 & 3 & 3 & 5 & 5 & 3 & 5 & 5 & 3 \\
\hline & & \multicolumn{2}{|c|}{ Practical knowledge } & 12.38 & 3 & 5 & 5 & 1 & 3 & 5 & 0 & 3 & 5 \\
\hline & & \multicolumn{2}{|c|}{$\begin{array}{l}\text { Organizational } \\
\text { Icadership }\end{array}$} & 7.02 & 3 & 3 & 0 & 0 & 0 & 1 & 0 & 1 & 0 \\
\hline & & \multicolumn{2}{|c|}{ Managenent ability } & 5.28 & 3 & 3 & 0 & 0 & 0 & 1 & 0 & 0 & 1 \\
\hline & Entrepreneur-i & \multicolumn{2}{|c|}{ innovalive abilily } & 13.17 & 3 & 3 & 3 & 3 & 0 & 3 & 0 & 3 & 5 \\
\hline & & \multirow{2}{*}{\multicolumn{2}{|c|}{$\begin{array}{l}\text { contumicication } \\
\text { ability } \\
\text { Proficssional } \\
\text { Luchnical ability }\end{array}$}} & 8.43 & 3 & 3 & 1 & 0 & 0 & 1 & 0 & 0 & 1 \\
\hline & & & & 12.37 & 5 & 3 & 5 & 3 & 3 & 3 & 3 & 3 & 3 \\
\hline \multicolumn{4}{|c|}{ Absolute importance degrese } & & 315 & 301 & 199 & $18 \times$ & 24 & $3 s$ & $s$ & 160 & 30 \\
\hline \multicolumn{4}{|c|}{ Rulative Imporlance degres } & & $"$ & $\therefore$ & 96 & $\because 2$ & ran & 16 & 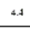 & 3 & th: \\
\hline \multirow{2}{*}{\multicolumn{3}{|c|}{$\begin{array}{l}\text { Technology } \\
\text { assessmen! }\end{array}$}} & \multicolumn{2}{|c|}{ L.ocal Liniversily } & 3 & 2 & 3 & 3 & 4 & 2 & 4 & 4 & 2 \\
\hline & & & Foreign univ & & 5 & 4 & 4 & 4 & 4 & 4 & 4 & 4 & 1 \\
\hline \multicolumn{5}{|c|}{ targect value } & 4 & 3 & 3 & 4 & 4 & 3 & 4 & 4 & 3 \\
\hline
\end{tabular}

According to the training plan of entrepreneurship education, teaching process and evaluation system, then 9 teaching measures are identified through expert discussion, training plan includes: setting up enterprise theory courses, practical courses, integration of courses with specialized courses; the teaching process includes classroom teaching, learning practice and social practice; the assessment system includes curriculum examination, academic achievement and practice achievement.

In the house of quality, there was a correlation between the demands of entrepreneurship education and teaching measures. 5 indicated strong correlation, 3 indicated correlation, 1 indicated weak correlation, and 0 indicated irrelevant. Through expert evaluation and scoring, the importance degree of entrepreneurship education is translated into the importance degree of teaching measures by using importance mapping algorithm. The greater the importance degree is, the closer relation to the demands of entrepreneurship education. Table 2 shows that the top four are: entrepreneurship education theory curriculum (15.5\%), practical curriculum (14.7\%), student achievement (14.7\%) and social practice (13.9\%). Which shows that entrepreneurship education should be based on theoretical study, and pay attention to practical activities. Entrepreneurship education can only enable students to really acquire knowledge in practice.Therefore, in the teaching design of entrepreneurship education, we should pay more attention to the basic knowledge, practical activities and assessment of practice for students, and the proportion of practice related teaching should be increased. Finally, according to the result of technical competition evaluation (domestic and foreign universities' index value), the target value of each factor in each teaching process design is determined.

\subsection{Teaching quality implementation of entrepreneurship education}

According to the target value of entrepreneurship education design elements, puts forward the elements of entrepreneurship education quality implementation, and through expert discussion, evaluation, and then determine the correlation degree between quality design and implementation module of entrepreneurship education, and construct the house of quality in teaching quality implementation of entrepreneurship education(see Table $3)$.

The teaching quality implementation of entrepreneurship education includes three parts: curriculum design, teacher resources. and supporting activities. Among them, the curriculum includes: curriculum system, entrepreneurial idea education; teacher resources include: teachers have entrepreneurial academic background, entrepreneurial practice experience, enterprise management experience, and effective teaching methods; the supporting activities including: providing entrepreneurial practice platform; entrepreneurial practical activities; financial support; System guarantee; School-enterprise cooperation. 
Table 3 the house of quality in teaching quality implementation of entrepreneurship education

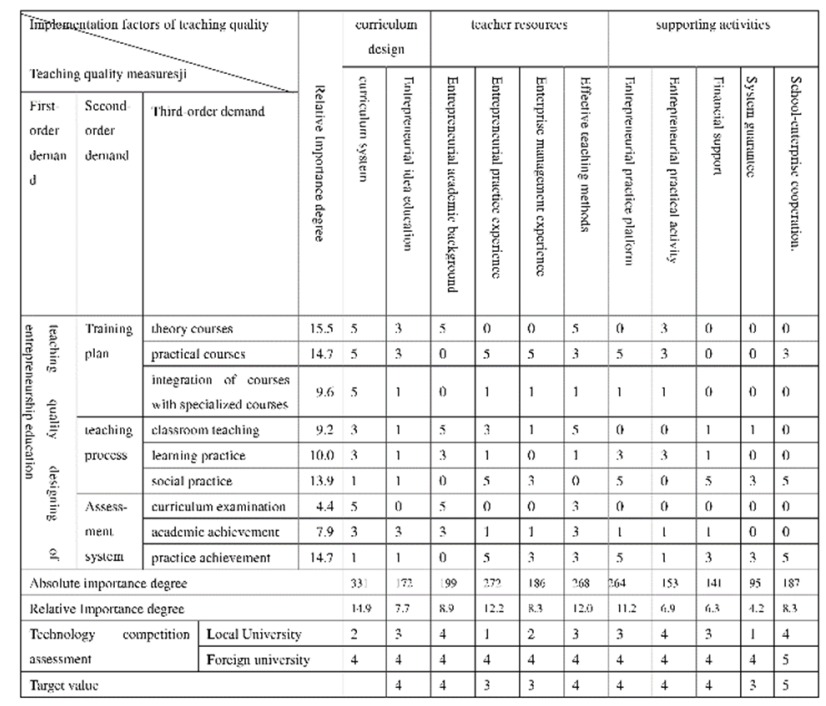

Through expert evaluation and scoring, the importance degree of entrepreneurship education design is transformed into the importance degree of teaching implementation by using importance mapping algorithm. The greater the importance degree is, the closer relation is to the elements of entrepreneurship education teaching quality design. As we can see from table 3, the top four are: curriculum system (14.9\%), teachers have entrepreneurial practice experience $(12.2 \%)$, effective teaching methods $(12 \%)$, and provide entrepreneurial practice platform $(11.2 \%)$. This shows that the implementation of entrepreneurship education in the teaching of specific process, it is very important for the quality of entrepreneurship education to choose the curriculum system suitable for students' development, the teacher's entrepreneurial experience and the appropriate teaching methods in the teaching, and the entrepreneurial platform offered by the universities. Finally, according to the results of technical competition evaluation (domestic and foreign universities and colleges), the target values of each factor in each teaching implementation process are determined.

\subsection{Teaching quality control of entrepreneurship education}

The main tasks of the teaching quality control phase of entrepreneurship education are to realize the demands of teaching quality implementation design management and control measures. The purpose of teaching quality control in enterprise education is to ensure the implementation of module quality control objectives, and to carry out each module goal to specific solutions. Combined with the nature of entrepreneurship education and the current situation of entrepreneurship education in local universities, the corresponding guarantee measures are put forward for each module of entrepreneurship education. So, to improve customer demand for entrepreneurship education has shifted to the functional unit of the teaching of each link are clear on the objectives and requirements, which makes the quality of entrepreneurship education improved more purposiveness and quality, to improve the whole process of entrepreneurship education.

\section{Contribution}

First, this paper takes local universities as an example, by means of the quality function deployment theory from the customer's needs, to explore the teaching quality of entrepreneurship education in design, implementation, control process, and then put forward the QFD model of teaching quality improvement of Entrepreneurship Education. Second, in all aspects of entrepreneurship education, the establishment of the implementation process and the stage goal of a series, through the realization of these goals to ensure the final effect of entrepreneurship education, so as to realize students of customer needs, develop to meet the social needs of new personnel and have the entrepreneurial potential needs of local economic development. Third, the improvement of teaching quality in entrepreneurship education is embodied in the following aspects: the process of entrepreneurship education is systematic and standardized; the focus of entrepreneurship education teaching is more prominent; establish a customer oriented approach to problem solving.

\section{Acknowledgment}

This work is financially supported by outstanding scholars of philosophy and Social Sciences in Henan Province higher education in 2018, 2018-YXXZ-06; Henan philosophy and Social Sciences Planning Project in 2019, 2019BJJ003; The social development project of Henan provincial key R \& D and promotion project (Science and technology tackling key problems) in 2019, project number: 515; Intellectual property soft science research project of Henan Province in 2021, 20210106014; Guangdong Education Science Planning Project, building an efficient and intelligent supply chain system to promote the high-quality economic development of GuangdongHong Kong-Macao Greater Bay Area, 2019GXJK072; Henan philosophy and Social Sciences Planning Project in 2019, 2019BJJ032; Key scientific and technological projects of Henan Province in 2021, 212102310051, Research on emergency decision-making mechanism and key technologies of major public emergencies; the key scientific research project of colleges and universities in Henan Province in 2021, 21A620002; General Topics of Henan Province Educational Science "13th Five-Year Plan" in 2020, Research on the dynamic mechanism of the integration of industry and education in Henan Province, 2020YB0146; Guangdong higher education reform project in 2020, No. 642, innovative research and practice of logistics personnel training mode based on new information technology under the background of new business. The project of quality engineering of Guangzhou College of Technology and Business in 2020, serial number 25, the exploration of the dynamic mechanism and path of the integration of production and education of undergraduate colleges in Guangdong-Hong Kong-Macao Greater Bay Area. Thanks for the help. 


\section{References}

1. Heinrichs, K. Dealing with critical incidents in the postformation phase: Design and evaluation of an entrepreneurship education course. Vocations and Learning,2016, 9(3), 257-273.

2. Mueller, S. Increasing entrepreneurial intention: Effective entrepreneurship course characteristics. International Journal of Entrepreneurship and Small Business, 2011, 13(1), 55-74.

3. Nabi, G., Liñán, F., Fayolle, A., Krueger, N., \& Walmsley, A. The impact of entrepreneurship education in higher education: A systematic review and research agenda. Academy of Management Learning \& Education, 2017, 16(2), 277-299.

4. Webster, R. D., \& Kopp, R. Case Study Of A Small Scale Polytechnic Entrepreneurship Capstone Course Sequence. American Journal of Engineering Education (AJEE), 2017, 8(1), 35-44.

5. Yamani, N., Mousavi, M., \& Haghani, F. Need Assessment of the Course "Entrepreneurship and Familiarization with Business" in Isfahan University of Medical Sciences. Iranian Journal of Medical Education, 2016, 16, 320-327.

6. Karimi, S., Biemans, H. J., Lans, T., Aazami, M., \& Mulder, M. (2016). Fostering students' competence in identifying business opportunities in entrepreneurship education. Innovations in Education and Teaching International, 53(2), 215-229.

7. Gonzalez, M. E., Quesada, G., Mueller, J., \& Mueller, R. D. (2011). International business curriculum design: identifying the voice of the customer using QFD. Journal of International Education in Business, 4(1), 6-29.

8. Liu Lipeng. Exploration on the cultivation path of Vocational College Students' innovation and entrepreneurship ability based on QFD theory [J]. Journal of Jiangxi Electric Power Vocational and technical college, 2020,33 (02): 95-96

9. Teng Fei. Research on teaching design of innovation and entrepreneurship education in Universities for Nationalities from the perspective of quality [J]. Science and technology entrepreneurship monthly, 2019,32 (06): 6-10

10. Zhang Junjie, Yang Li. Analysis of influencing factors and promotion strategies of entrepreneurial ability of Application-oriented College Students Based on QFD theory [J]. Modern education science, 2019, (05): 123-127

11. Li Ning. Research on Effective Cultivation of entrepreneurial talents in Colleges and Universities Based on QFD [J]. China Adult Education, 2017, (18): 71-74 